\title{
Peceneaga-Camena Fault: Geomagnetic insights into active tectonic contact
}

\author{
(c) L. Besutiu ${ }^{1}$, M. Orlyuk ${ }^{2}$, L. Zlagnean ${ }^{1}$, A. Romenets ${ }^{2}$, \\ L. Atanasiu ${ }^{1}$, I. Makarenko ${ }^{2}, 2014$ \\ ${ }^{1}$ Institute of Geodynamics of the Romanian Academy (IGAR), \\ Bucharest, Romania \\ ${ }^{2}$ Institute of Geophysics National Academy of Sciences of Ukraine, \\ Kiev, Ukraine
}

Received 18 July 2013

Presented by Editorial Board Member V. I. Starostenko

\begin{abstract}
Highly detailed, very accurate ground magnetic investigations were jointly conducted by Romanian and Ukrainian researchers on a segment of the Peceneaga-Camenas Fault (PCF) in order to reveal the potential of geomagnetic method for active faults investigating. The survey succeeded to outline the PCF track in the area covered by recent sediments, and provide insights on the fault structure and in-depth development. 2D numerical modeling has been employed for interpreting the obtained geomagnetic anomaly. Lateral variations in magnetization, as suggested by the model, reveal the complex geological architecture in the area, hidden by recent deposits. The zero magnetization outlined in the central part of the survey lines has been interpreted in geodynamic terms, as a breccias zone created along PCF track by its active dynamics.
\end{abstract}

Key words: magnetic survey, magnetization, residual geomagnetic anomaly, modeling, faults, geodynamics.

\section{Печенежско-Каменский разлом: геомагнитная оценка активного тектонического контакта}

\author{
(c) Л. Бешутью, М. Орлюк, Л. Злагнеан, А. Роменец, \\ Л. Анастасью, И. Макаренко, 2014
}

С целью оценки возможностей геомагнитного метода при изучении активных разломов совместно с румынскими и украинскими учеными были выполнены высокоточные наземные исследования Печенежско-Каменского разлома (ПКР). Съемка позволила проследить положение ПКР под современными осадочными образованиями и получить представление о его глубинной структуре. Интерпретация выделенных вдоль профилей магнитных аномалий была выполнена с помощью двумерного численного моделирования. В соответствии с моделью, латеральные вариации намагниченности исследуемой зоны свидетельствуют о сложном геологическом строении, скрытом под молодыми осадками. Область коры с нулевой намагниченностью, которая выделена в центральной части геомагнитных профилей, проинтерпретирована с геодинамичеких позиций как пояс брекчированных пород, образованных вдоль ПКР вследствие активных перемещений по нему.

Ключевые слова: магнитная съемка, намагниченность, остаточная геомагнитная аномалия, моделирование, разломы, геодинамика. 
General consideration. The Peceneaga-Camena Fault (PCF) represents one of the most studied tectonic features in the Romanian territory, even from the beginning of the $20^{\text {th }}$ century [Mrazec, 1912; Macovei, 1912]. It generally appears (Fig. 1) as the boundary between the Moesian Platform (MP), represented in the area by Central Dobrogea (CD), and North Dobrogea (ND) geological units.

During the time, PCF has been alternately considered as a simple reverse fault [Macovei, 1912], or the over thrusting plan of the hypothetic Green Schists Nappe [Preda, 1964]. More recent research pointed out its strike-slip nature [Sandulescu, 1980; Gradinaru, 1984; Hippolyte etal., 1996; Besutiu, 1997; Banks, Robinson, 1997].

Geophysics brought significant evidence on the PCF in-depth extent. The international deep seismic soundings (DSS) line № 2 [Radulescu et al.,
1976] has revealed its crustal nature, showing a step of about $10 \mathrm{~km}$ at the both Conrad and Moho discontinuities. Later on, seismic tomography images based on CALIXTO experiment [Martin et al., 2006], have revealed PCF as a major lithospheric contact between East European Plate (EEP) and Moesian Micro-plate (MoP) reactivated during the W Black Sea opening [Besutiu, Zugravescu, 2004; Besutiu, 2009].

Geological evidence shows a PCF geodynamic evolution during the time with both right-lateral and left-lateral slip episodes [Pavelescu, Nitu, 1977; Sandulescu, 1980; Gradinaru, 1984; 1988; Seghedi, Oaie, 1995; Banks, Robinson, 1997; Cosma et al., 2010].

The Baspunar Geodynamic Observatory (BGD) was especially designed and run by the Solid Earth Dynamics Department at the Institute of Geodynamics of the Romanian Academy in order to moni-

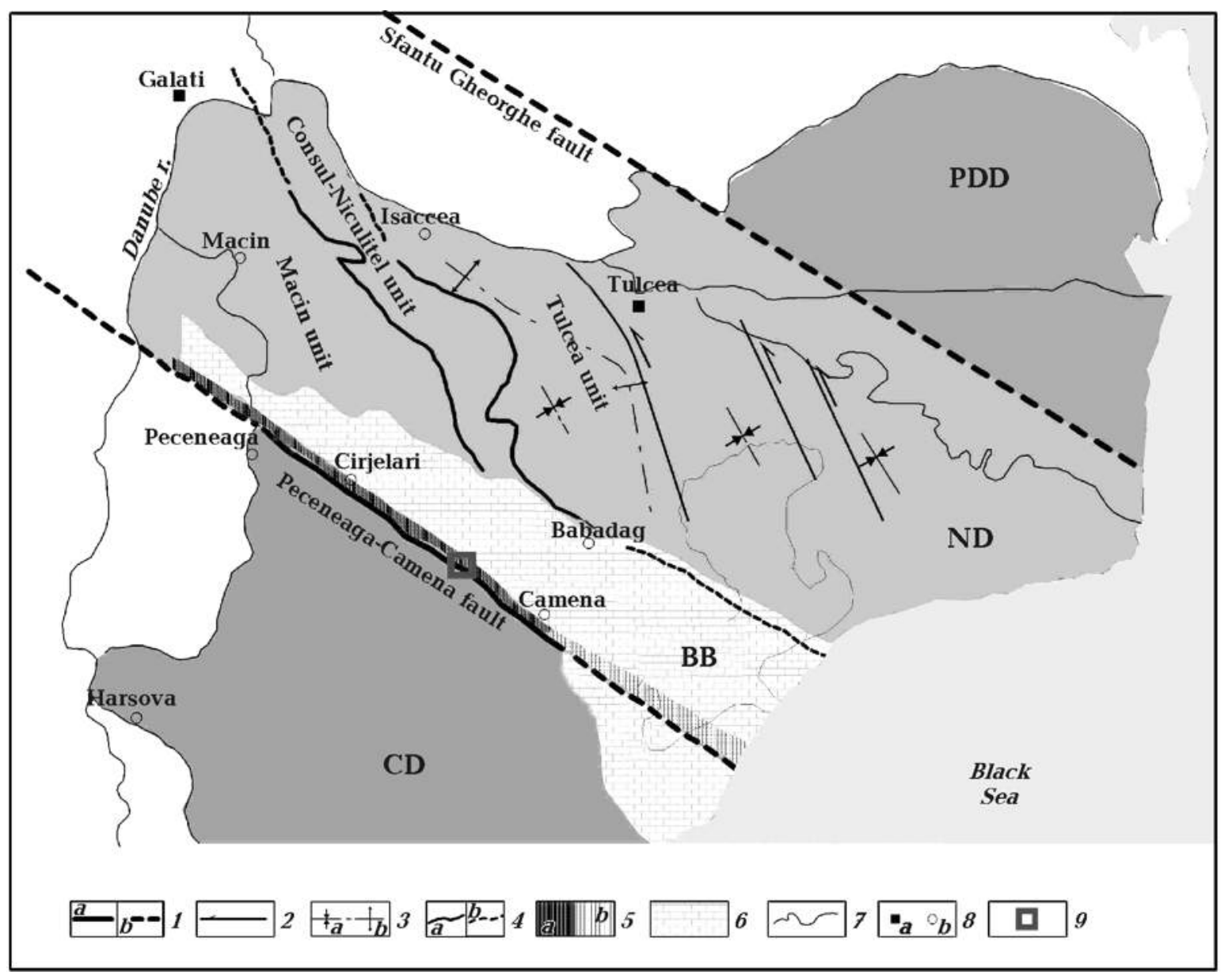

Fig. 1. Simplified tectonic setting of PCF and location of the study area: 1 - North Dobrogea boundaries (a cropping out, $b-$ covered); 2 - strike-slip faults; 3 - structural axes $(a-$ syncline, $b-$ anticline); $4-$ boundaries between North Dobrogea main units ( $a$ - cropping out; $b$ - buried); 5 - Cirjelari-Camena Outcrop Belt $(a-$ cropping out, $b$ - covered); 6 - episutural post-tectonic cover; 7 - river; 8 - settlements ( $a$ - major cities; $b$ - villages); 9 - Baspunar Geodynamic Observatory (BGD) location; PDD - Predobrogean Depression; ND - North Dobrogea; CD - Central Dobrogea; BB - Babadag Basin. 


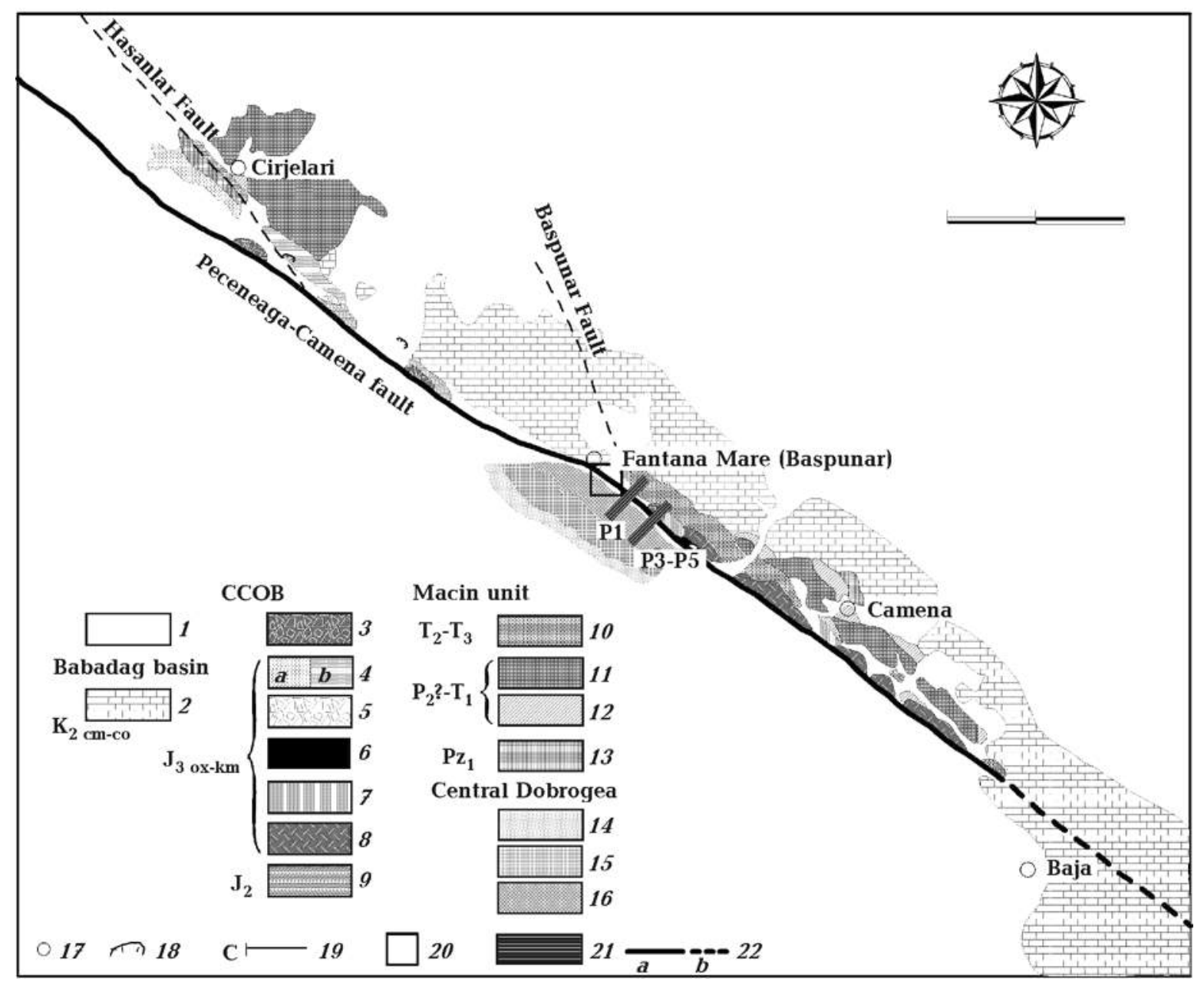

Fig. 2. Simplified geologic sketch of the study area (modified after [Gradinaru, 1988]): 1 - Quaternary; 2 Babadag basin, Episutural sedimentary cover; 3-9 - CCOB (3 - Baspunar Melange; 4 - Formation Sfanta (a), Amara Formation (b), 5 - Amara Breccia; 6 - Baspunar Spilite; 7 - Baspunar Formation; 8 - Camena Rhyolite; 9 - Aiorman Formation); 10-13 - Magin unit (10-Uspenia Formation, 11 - Cirjelari Rhyolite, $12-$ Camena Formation, 13 - Lower Paleozoic (marbles, quartzites and argillites)); 14-16 - Central Dobrogea (14 - Infragrauwacke, 15 - Lower Grauwacke, 16 - Upper Grauwacke), 17 - settlement; 18 - quarry; 19 cross-section location; 20 - BGD; 21 - magnetic survey panel; 22 - PCF track ( $a$ - exposed, $b-$ covered).

tor slip along PCF. This paper mainly deals with results of the high accuracy detailed magnetic investigations carried out on the PCF segment located in the neighborhood of the BGD, aimed at revealing the path and in-depth structure of the PCF in the monitoring area. Research has been carried out in the frame of the bi-lateral project INRAF ("Integrated research of some active faults located in the NW inland of the Black Sea on the Romanian and Ukrainian territories"), jointly developed by the Institute of Geodynamics of the Romanian Academy and the Institute of Geophysics of the National Academy of Sciences of Ukraine.

The local geological background. North Dobrogea. The area subject to geophysical investigation mainly belongs to the so called Cirjelari-Ca- mena Outcrop Belt (CCOB). A thorough description of the structure and lithostratigraphy of this unit was provided by Gradinaru [Gradinaru 1980, 1984, 1988], and a simplified geological sketch for the study area is shown in Fig. 2, along with the location of the magnetically surveyed panels.

On the overall, the study area is dominated by the presence of the Jurassic sedimentary and volcanic rocks, unconformable overlying older Palaeozoic deposits of the Macin Unit and largely covered by the post-tectonic sedimentary cover of the Cretaceous Babadag Basin and shallow Quaternary formations.

The Quaternary rocks are mainly represented by shallow layers of loess deposits.

The Babadag Basin comprises two main Upper Cretaceous formations: lancina and Dolosman se- 
ries mainly consist of limestone and sandstone, with transient facia (between sandy limestone and limy sandstones). Overall, the Upper Cretaceous does not contain any source of geomagnetic anomalies, except for some residual red shale deposits, locally developed within confined volumes, but able to provide slight geomagnetic effects at the surface [Besutiu, Nicolescu, 1999]).

Jurassic rocks of CCOB (Gradinaru, herein) may be grouped into several main sedimentary formations $(F m)$ :

- Cirjelari Fm $\left(J_{3 \text { ox-km }}\right)$ is composed of: 1$)$ gaizes, spongolites, tuffittes, 2) polimictic conglomerates, 3) (marly and silty) shales, 4) bioclastic calcarenites and calcirudites, 5) oolitic calcarenites. Also in the Cirjelari Fm mixtites with Green Schist clasts, Cirjelari Rhyolite clasts, and oligomictic conglomerates may occur;

- Baspunar Fm $\left(J_{30 x}\right)$ consists of: 1$)$ gaizes, spongolites, tuffittes, 2) crinoidal calcarenites, marlstones, marly shales, 3) rhyolitic tuffs at the bottom;

- Aiorman $\mathrm{Fm}\left(\mathrm{J}_{2}\right)$ is composed of terrigenous turbidites;

- Movila Goala Fm $\left(J_{2}\right)$ consists of: 1 ) terrigeneous turbidites, 2) black oolitic calcarenites, 3) crinoidal calcarenites, bottomed by calcitized rhyolite lava flows. Another two special tectono-stratigraphic units should be also mentioned: the Amara breccia $\left(J_{3}\right)$ and Baspunar Melange, with metabasic rocks, probably shared remnants of an incipiently developing oceanic crust in the final stage of CCOB [Gradinaru, 1984];

- the Amara Breccia $\left(J_{3 \text { ox-km }}\right)$ has been interpreted [Gradinaru, 1984] as a shared remnant of a former more extensive talus breccias. It is a clast supported monomictic breccias consisting of elements belonging to CD "Green Schist" series, and several levels of carbonates rocks from the Cirjelari Fm, with a carbonate matrix;

- the Baspunar Melange occurred later on (Late Jurassic), when the movement along PCF became left-lateral. It contains blocks of Lower Palaeozoic marbles and quartzites of the Macin unit, but also blocks of Jurassic sedimentary and metabasic rocks.

The Triassic deposits (Uspenia Fm) mainly consist of gray limestone [Mirauta, Mirauta, 1961].

The Palaeozoic formations are practically hidden by younger deposits, except for some confined areas where they may crop out (Cirjelari valley, where Aiorman Fm unconformable lies on Palaeozoic basement rocks).

According to [Mirauta, Mirauta, 1961; Mirauta, 1966] the Palaeozoic deposits in the area mainly consist of Devonian (philite, limestone, serricite-chlo- rite schist), and Carboniferous, represented by Carapelit Fm (conglomerates, sandstones and schist series).

The bimodal (acid and basic) CCOB volcanic rocks may be grouped into Camena Rhyolite $\left(\mathrm{Pz}_{3}\right)$ and Baspunar spilite $\left(J_{3}\right)$.

The Camena Porphyries $\left(T_{3}\right.$ ?) crop out between Cara Burun Hill (Camena) and Baspunar, and seem to be connected to the tectonic lineament Baspunar-Camena. They pierce the Proterozoic crystalline series, but occur as remnants in the Liassic conglomerates. They have been described as micro-granites accompanied by dykes [Mirauta, Mirauta, 1961], tuffs, ignimbrites and lava flows [Gradinaru, 1984].

The Baspunar spilite $\left(J_{3}\right)$ is mainly represented by pillow-lava flows interbeded in Jurassic limestone.

Central Dobrogea (CD). South PCF, CD deposits are mainly represented by the Upper Proterozoic Green Schist Series (GSS), largely described during the time by various authors [Mrazec, 1910, 1912; Macovei, 1912; Mirauta, Mirauta, 1961; Mirauta, 1964, 1965, 1969; Paraschiv, Paraschiv, 1978].

Mirauta describes several horizons of increasing (top to bottom) grade metamorphic rocks [Mirauta, 1964]:

1) upper grauwacke (grauwacke, siliceous schists, micro-conglomerates);

2) lower grauwacke (grauwacke, schists);

3) infragrauwacke (green philites, green chloritic quartzites (meta-grauwacke).

The infragrauwacke series are bottomed by some mezzo- to high-grade metamorphic rocks (micaschiste, quartzites, amphibolytes) occurring in the axis of the reverse mega-anticline structure Ceamurlia-Baspunar (Mirauta, herein). They are considered by various authors [Besutiu, 1997] as the source of the regional geomagnetic high overlying the axis of the Baspunar-Camena-Ceamurlia anticline.

Since early times, it has been also noticed [Motas, 1913] that CD deposits in the PCF contact zone are sometimes intercalated with, or intruded by magmatic rocks of North Dobrogea (rhyolites), which might represent another source for geomagnetic anomalies.

Data acquisition and processing. Field observations were conducted by using two G $856 \mathrm{AX}$ magnetometers (one for the record of diurnal geomagnetic activity, and the second one for observations along the survey lines).

Basically, the survey lines were designed almost perpendicular to the assumed PCF track. The lines are $4 \mathrm{~m}$ apart, and a step of $2 \mathrm{~m}$ between two consecutive stations along each line was used to survey the study area. Location of data points was set by using a Garmin 78 GPS receiver. The geographic coordinates on WGS 1984 ellipsoid were then transferred into the rectangular coordinates 

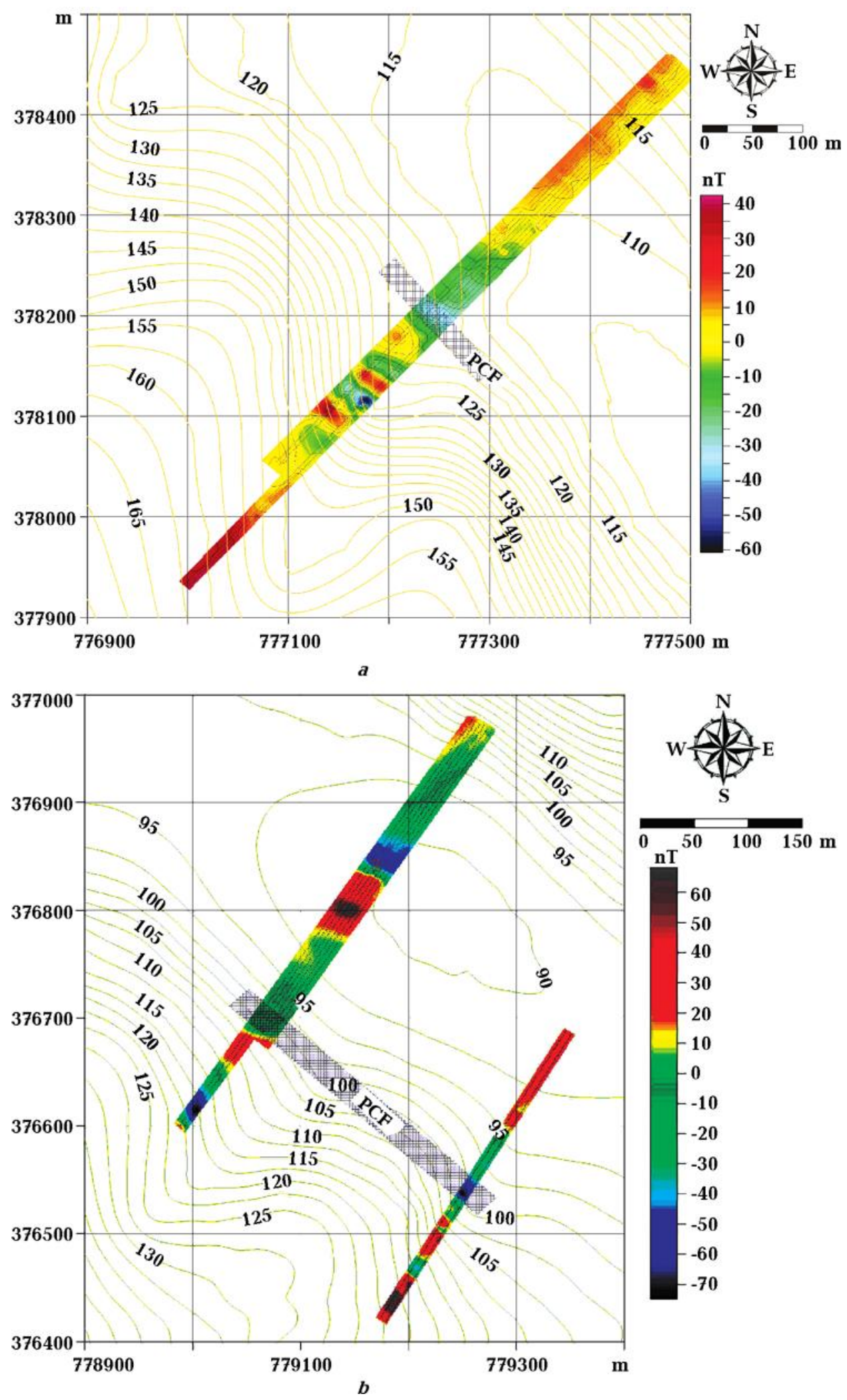

Fig. 3. Residual geomagnetic anomaly along various PCF segments (a - micro-panel $\mathrm{P} 1, b-$ micro-panels P3-P5) as obtained after removing a first order polynomial trend. Black dots mark data points. Brown solid lines show topography contours (in meters). Dashed zone marks the assumed PCF track. 


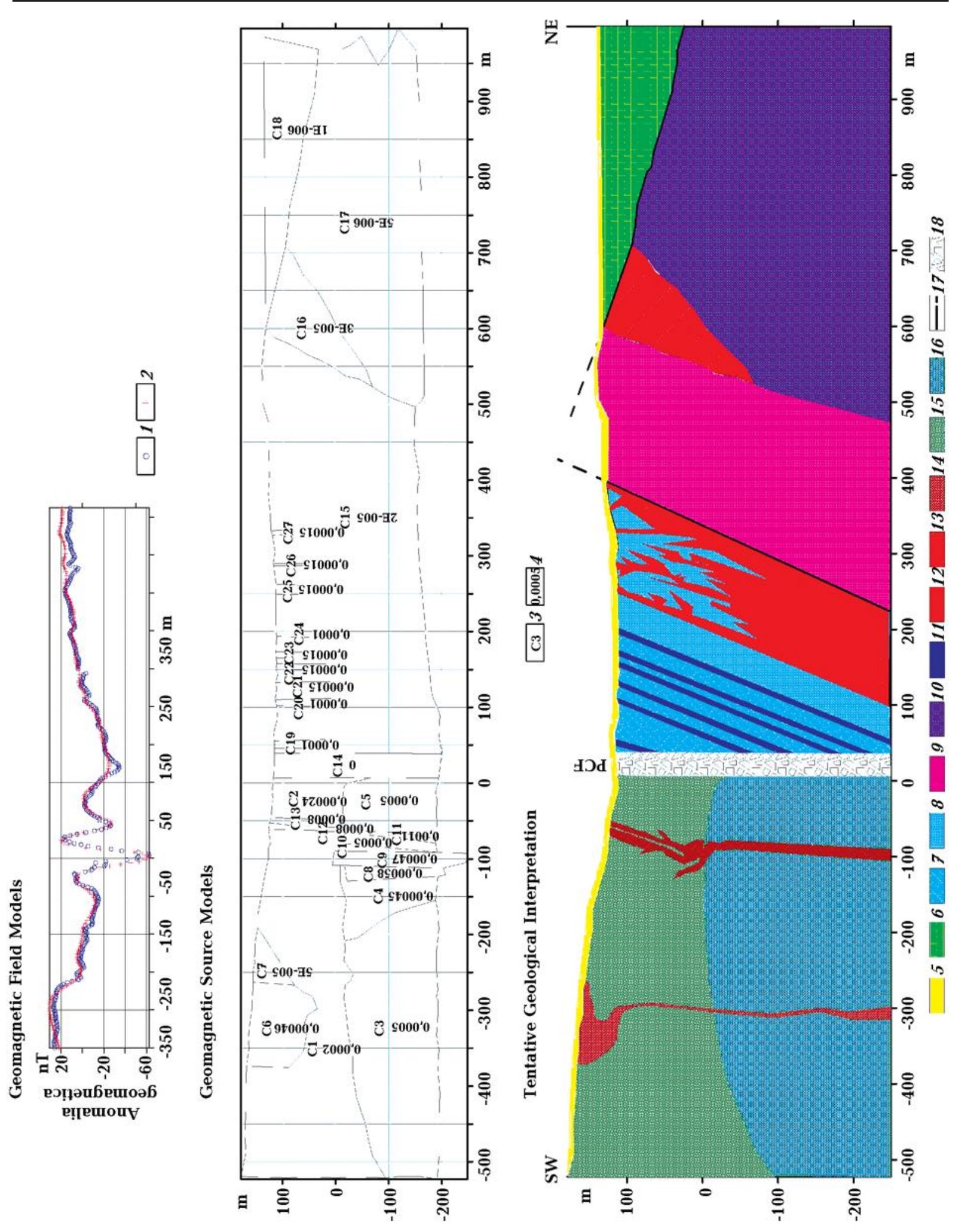

Fig. 5. Tentative interpretative model of the geomagnetic anomaly across PCF: 1 - residual geomagnetic anomaly, 2 - predicted field, 3 - body ID, 4 - magnetic susceptibility (in $10^{-6} \mathrm{CGSu}$ ); $5-13$ - North Dobrogea (5-loess, 6 - post-tectonic cover (K2), 7 - Upper Jurassic limestone, 8 - Lower Jurassic, 9 - Triassic limestone, 10 - Camena Fm (P2-T1), 11 - Baspunar spilite, 12 - Camena Porphyry, 13 - Cirjelari Rhyolite); 14-18 - Central Dobrogea (14 - diorite dykes, 15 - low-grade GSS, 16 - higher-grade GSS, 17 - secondary fault, 18 - breccias zone generated by fault dynamics). 
of the Romanian national stereographic projection system [Avramiuc et al., 2001].

The geomagnetic sensor was placed at $3 \mathrm{~m}$ above the ground in order to avoid (or at least to mitigate) shallow local effects.

Diurnal geomagnetic activity was observed and recorded every minute during the survey in a local base-station, located close to the surveyed area.

Routine processing has been applied to the raw observations in order to provide data consistency: removal of the effect of external sources and base reduction.

As a result, a time-invariant $\Delta T$ as referred to the survey base-station was obtained. Finally, a residual geomagnetic anomaly was computed by removing a first-order polynomial trend from the observations, and $\Delta T_{\mathrm{a}}$ geomagnetic maps were plotted (Fig. 3).

Modeling geomagnetic sources. Taking into consideration the pattern of the geomagnetic anomaly and some previous information on the study area, attempts for modeling the geomagnetic sources and their geological interpretation have been performed.

The software. The professional GM-SYS $B$ software run on the Geosoft OASIS $\AA$ platform has been used for 2D modeling along the survey lines. It is based on the methods proposed by [Talwani et al., 1959; Talwani, Heirtzler, 1964], and employs algorithms published by [Won, Bevis, 1987].

Rocks magnetic properties. Magnetic properties of the rocks in the area have been conside- red according to previous rock physics determinations [Besutiu, 1997; Besutiu, Nicolescu, 1999], to which additional determinations on outcrops samples were performed in the IG-NASU laboratory.

Table 1 shows some magnetic properties of the main geological formations within North Dobrogea and the study area.

Polarizing field. As Köenigsberger coefficient $(Q)$ of the geological formations known in the study area generally shows small values, the induced magnetization model has been considered during the computation, with the following parameters for the polarising field:

- total intensity field $T=48500 \mathrm{nT}$,

- geomagnetic inclination $I=62^{\circ} \mathrm{N}$,

- geomagnetic declination $D=3^{\circ} \mathrm{E}$.

Physical model. Two main aspects of the modeling should be stressed:

- to get a better fit between the observed and predicted anomaly, laterally extended geomagnetic source models (exceeding the survey line) were taken into consideration;

- due to the close vicinity of the survey lines, similar geomagnetic patterns, and, consequently, except for small lateral changes in geometry, rather similar models of the sources of the geomagnetic anomalies as showed in the followings were outlined along various lines.

Basically, following the trial \& error process of 2D modeling along the survey lines the best fit has been obtained for the geometry and rock magnetic properties as illustrated in Fig. 4.

Geomagnetic Field Models
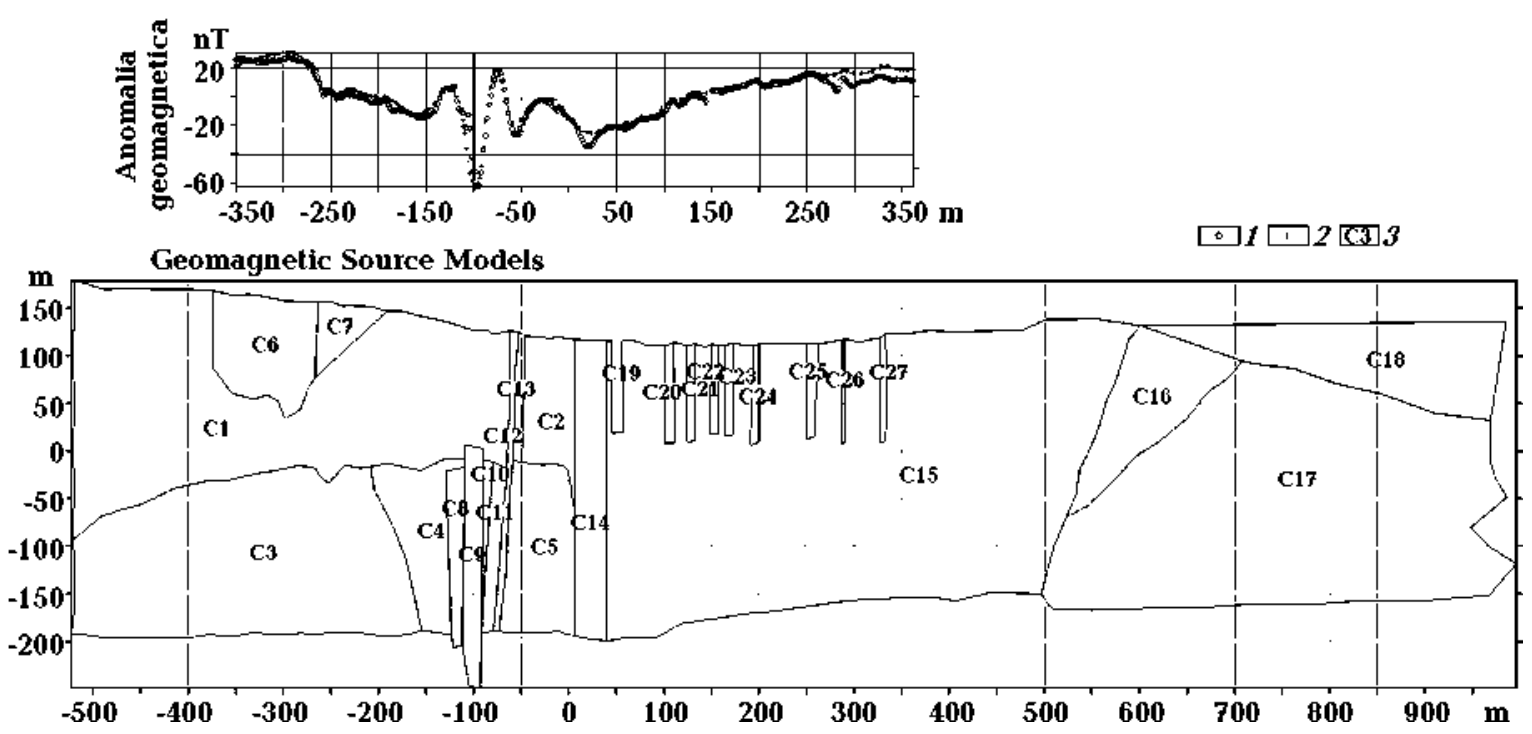

Fig. 4. Physical model for the source of the residual geomagnetic anomaly along the line $P$ : 1 - observed field, 2 - predicted effect, 3 - magnetic body ID (see Table 2). 
T a b l e 1. Magnetic properties of the main geological formations of North Dobrogea and CCOB

\begin{tabular}{|c|c|c|}
\hline Geology & $\begin{array}{c}\text { Magnetic } \\
\text { susceptibility } \\
\text { range } \\
\left(10^{-6} \mathrm{CGSu}\right)\end{array}$ & $\begin{array}{c}\text { Average } \\
\text { Königsberger } \\
\text { coeficient } \\
(Q)\end{array}$ \\
\hline \multicolumn{3}{|c|}{ North Dobrogea } \\
\hline \multicolumn{3}{|c|}{ Tulcea Unit } \\
\hline Triassic basalts & $278-450$ & 0,41 \\
\hline Dolerite (Marca) & $189-252$ & \\
\hline Quartzite diorite (Cazalgic Bair) & $682-1276$ & 0,16 \\
\hline Granite-diorite (Cazalgic Bair) & $88-162$ & 0,15 \\
\hline \multicolumn{3}{|c|}{ Niculitel sub-unit } \\
\hline Mafic rocks (basalte, spilite) & $539-1322$ & 1,85 \\
\hline Rhyolite (Isaccea) & $50-102$ & 0,33 \\
\hline \multicolumn{3}{|c|}{ Consul sub-unit } \\
\hline Rhyolite (P. Rosie, Consul) & $198-409$ & 1,01 \\
\hline weathered (Iulia) & $214-236$ & \\
\hline highly weathered (Consul) & $13-36$ & 1,25 \\
\hline \multicolumn{3}{|c|}{ Magin Unit } \\
\hline Dolerite (Galma) & $270-496$ & 0,64 \\
\hline Dolerite (Macin—Hamcearca) & $765-1734$ & 1,16 \\
\hline Dolerite (Greci) & $67-71$ & 0,17 \\
\hline Biotitic granite (Vacareni) & $248-465$ & 7,11 \\
\hline Biotitic granite (Pricopanu) & $9-15$ & 0,25 \\
\hline Leuco-granite (Macin-Coslugea) & $169-328$ & 0,25 \\
\hline Alkali-granite & $797-1120$ & 0,29 \\
\hline Granodiorite (Greci) & $467-790$ & 0,12 \\
\hline Diorite (Greci/Vacareni) & $724-1428$ & 16,68 \\
\hline Contacts: Carapelit Fm/granite & $774-2056$ & 0,22 \\
\hline Boclugea series/granite & $1040-2740$ & 5,59 \\
\hline $\begin{array}{l}\text { Megina crystalline series: } \\
\text { vulcanogen-felsic }\end{array}$ & $78-158$ & 5,47 \\
\hline amphibolites & $786-2464$ & 2,82 \\
\hline Orliga crystalline series & $144-629$ & 2,05 \\
\hline \multicolumn{3}{|c|}{$\mathrm{CCOB}$} \\
\hline Quaternary-loess & $0-15$ & 0,5 \\
\hline $\begin{array}{l}\text { Episutural sedimentary cover } \\
\text { (limestone) }\end{array}$ & $1-5$ & 0,3 \\
\hline Cirjelari Fm & $1-10$ & 0,2 \\
\hline Baspunar Fm & $1-13$ & 0,3 \\
\hline Aiorman Fm & $0-11$ & 0,1 \\
\hline Camena rhyolite & $30-120$ & 0,7 \\
\hline Baspunar spilite & $100-300$ & 1,5 \\
\hline Cirjelari rhyolite & $50-150$ & 0,8 \\
\hline Diorite (dykes) & $400-1200$ & 1,8 \\
\hline \multicolumn{3}{|c|}{ Central Dobrogea } \\
\hline Upper (low-grade) grauwacke & $80-230$ & 0,5 \\
\hline Infra (high-grade) grauwacke & $280-630$ & 1,5 \\
\hline
\end{tabular}


T a b l e 2 . Magnetic properties of the source model

\begin{tabular}{|c|c|c|}
\hline $\begin{array}{l}\text { Body } \\
\text { ID }\end{array}$ & $\begin{array}{c}\text { Magnetic } \\
\text { susceptibility } \\
\text { (CGSu) }\end{array}$ & Potential geological significance \\
\hline $\mathrm{C} 27$ & 0,000150 & Baspunar spilite \\
\hline $\mathrm{C} 26$ & 0,000150 & Baspunar spilite \\
\hline $\mathrm{C} 25$ & 0,000150 & Baspunar spilite \\
\hline $\mathrm{C} 24$ & 0,000100 & Baspunar spilite \\
\hline $\mathrm{C} 23$ & 0,000150 & Baspunar spilite \\
\hline $\mathrm{C} 22$ & 0,000150 & Baspunar spilite \\
\hline $\mathrm{C} 21$ & 0,000150 & Baspunar spilite \\
\hline $\mathrm{C} 20$ & 0,000100 & Camena rhyolite?/Baspunar spilite? \\
\hline C19 & 0,000100 & Camena rhyolite?/Baspunar spilite? \\
\hline C18 & 0,000001 & $\begin{array}{c}\text { Sandy limestone (Cretaceous post-tectonic } \\
\text { cover) }\end{array}$ \\
\hline $\mathrm{C} 17$ & 0,000005 & Camena Fm \\
\hline $\mathrm{C} 16$ & 0,000030 & Cirjelari rhyolite \\
\hline C15 & 0,000020 & Triassic limestones (Uspenia Fm) \\
\hline $\mathrm{C} 14$ & 0,000000 & Milonites/breccia (Baspunar melange) \\
\hline $\mathrm{C} 13$ & 0,000800 & Diorite (partly weathered) \\
\hline $\mathrm{C} 12$ & 0,000800 & Diorite (partly weathered) \\
\hline C11 & 0,001100 & Diorite (fresh) \\
\hline C10 & 0,000500 & Weathered diorites?/infragrauwacke? \\
\hline C9 & 0,000470 & Weathered diorites?/infragrauwacke? \\
\hline $\mathrm{C} 8$ & 0,000580 & Weathered diorites?/infragrauwacke? \\
\hline $\mathrm{C} 7$ & 0,000050 & Highly weathered zone (fault?/fissure?) \\
\hline C6 & 0,000460 & Weathered diorites?/infragrauwacke? \\
\hline C5 & 0,000500 & Infragrauwackee \\
\hline $\mathrm{C} 4$ & 0,000450 & Infragrauwackee \\
\hline $\mathrm{C} 3$ & 0,000500 & Infragrauwackee \\
\hline $\mathrm{C} 2$ & 0,000240 & Lower grauwacke \\
\hline $\mathrm{C} 1$ & 0,000200 & Lower grauwacke \\
\hline
\end{tabular}

Overall, to predict the geomagnetic anomaly, several 2D magnetic bodies have been considered. Table 2 shows their magnetic susceptibilities along with the assumed geological significance.

Geological interpretation. Based on previously gathered tectonic knowledge and rock physics of the main geological formations occurring in the study area and neighbouring region, an attempt for interpreting the geomagnetic sources outlined by modeling has been made. The results are synthetically illustrated in Fig. 5. As previously mentioned, the interpretative geological cross-section laterally extends over the magnetic line in order to mitigate the effect of the signal truncation and side effects.
Overall, the geological interpretation of the synthetic model has allowed outlining the PCF path by separating PCF flanks due to the general distinct geomagnetic behaviour of their different embedded geological formations (basically magnetic CD Proterozoic GSS versus non-magnetic ND Palaeozoic sedimentary).

But, the survey accuracy has also allowed discriminating some distinct layers with different magnetization within GSS, as well as the presence of some intrusive rocks (diorite dykes?) penetrating the geological formations.

On the other hand, basalt flows (Başpunar spilite) embedded within the Başpunar Fm (Jurassic and/or Triassic limestone) significantly complicate 
the interpretation by locally increasing the geomagnetic behaviour of the respective sedimentary pile.

Revealing the PCF track. Taking into consideration the peculiarities of the geomagnetic field pattern over the two flanks of the PCF, and the results of the quantitative interpretation of the 2D modeling along the survey lines, PCF track could be clearly outlined in the areas covered by recent deposits except for some confined areas due to the insufficient westward extension of the survey lines Fig. 6.

Geodynamic considerations. One interesting aspect pointed out by the geomagnetic modeling has been the apparent lack of magnetic properties in the central compartment of the interpreta- tive cross-section, located along the assumed PCF track.

This has been interpreted in terms of fragmentation of the PCF flanks, generating rock-debris through the abrasion of the fault flanks as a consequence of its active slip. Despite some initial individual magnetic properties, on the overall, elements of this compartment may not be reflected in the pattern of the geomagnetic anomaly due to the current of randomly distributed direction of magnetization of the breccias elements. Besides, water circulating within the contact zone accelerated the magnetic minerals weathering and, consequently, the loss/mitigation of original magnetic properties.
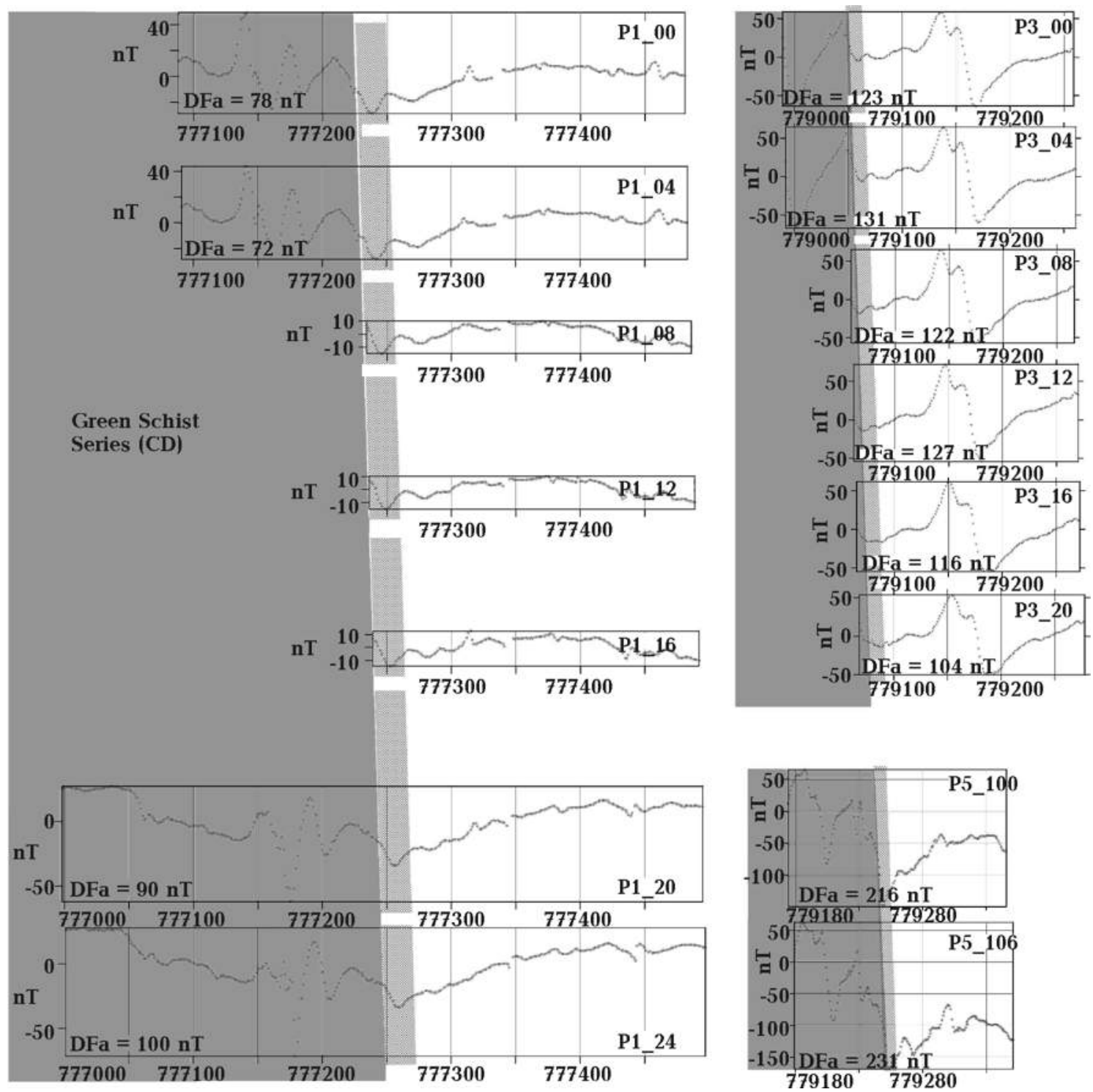

Fig. 6. PCF imprint in the pattern of the residual geomagnetic anomaly along various survey lines. Fault track is marked by the blue dashed zone. 
Concluding remarks. Detailed high accuracy ground magnetic survey on a PCF segment located in the vicinity of BGD succeeded to outline the fault track and in-depth structure, based on the interpretation of some $2 \mathrm{D}$ models simulating sources of geomagnetic effects.

The active character of the fault has been indirectly revealed through the loose of magnetic be-

\section{References}

Avramiuc N., Dragomir P. I., Rus T., 2001. Algorithm for direct and inverse coordinate transformation between ETRS89 CRS and S-42 CRS. J. Geosdesy and Cadastre, 105-114.

Banks C. J., Robinson A., 1997. Mesozoic strikeslip back-arc basins of the western Black Sea region. In: A. G. Robinson (Ed.). Regional and Petroleum Geology of the Black Sea and Surrounding Region. AAPG Mem. 68, 53-62.

Besutiu L.,1997. Contributions to the modeling of the transient zone between North Dobrogea inland and the Black Sea off-shore, based on the interpretation of geophysical data by using modeling technique: Ph. D. thesis, University of Bucharest, 206 p. (in Romanian).

Besutiu L., 2009. Geodynamic and seismotectonic setting of the SE Carpathians and their foreland. In: L. Besutiu (Ed.) Integrated research on the intermediate depth earthquakes genesis within Vrancea zone. Vergiliu Publ. House, P. 233248.

Besutiu L., Nicolescu A., 1999. Old and new geophysical images within North Dobrogea Orogen: Proceedings of "Dobrogea - the interface between Carpathians and the Trans-European Suture Zone" - Joint Meeting of TESZ, PANCARDI and GEORIFT projects. Rom. J. Tect. Reg. Geol., P. 54.

Besutiu L., Zugravescu D., 2004. Considerations on the Black Sea opening and related geodynamic echoes in its NW inland as inferred from geophysical data interpretation. Ukrainian Geologist (3), 51-60.

Cosma C., Dinu A., Papp B., Begy R., Gabor A., Brisan N., Besutiu L., 2010. Radon implication in the life and Earth Science. Workshop, NAMA 2010 (Nuclear Analytical Methods and Applications), Bucuresti, 3-4 Nov 2010.

Gradinaru E., 1984. Jurassic rocks of north Dobro- haviour in the contact area of the PCF flanks, where active slip produced a chaotic distribution of magnetization of the rock-debris.

Within the joint international effort of the Romanian and Ukrainian specialists, the experiment succeeded to demonstrate the potential of the old geomagnetic method for investigating structure and dynamics of some active faults.

gea. A depositional-tectonic approach. Rev. Roum. Géol., Géophys. Géogr. 28, 61-72.

Gradinaru E., 1988. Jurassic sedimentary rocks and bimodal volcanics of the Cirjelari-Camena outcrop belt: evidence for a transtensile regime of the Peceneaga-Camena Fault. St. Cerc. Geol. Geofiz. Geogr. (Geol.) 33, 97-121.

Gradinaru E., 1980. Rocile sedimentare si vulcanitele acide si bazice ale Jurasicului superior (Oxfordian) din zona Camena (Dobrogea de Nord). An. Univ. Buc. XXX, 80-110.

Hippolyte J.-C., Sandulescu M., Badescu D., Badescu N., 1996. L'activité d'un segment de la ligne Tornquist - Teisseyre depuis le Jurassique supérieur: la faille de Peceneaga-Camena (Roumanie). C. R. Acad. Sci. Paris 323 (Série Ila), 1043-1050 (in Romanian).

Macovei G.,1912. Observations sur la ligne de chevauchement de Pecineaga (Dobrogea). C. R. Inst. Geol. III, P. 155.

Martin M., Wenzel F. and the CALIXTO Working Group, 2006. High resolution teleseismic body wave tomography beneath SE Romania, II. Imaging of a slab detachment scenario. Geophys. J. Int. 164, 579-595.

Mirauta O., 1966. Devonianul si Triasicul din dealurile Mahmudiei (Devonian and Triassic of the Mahmudia hills). D. S. Inst. Geol. Rom. LII (2), 115-155 (in Romanian).

Mirauta O., 1964. Sisturile verzi din regiunea Dorobantu-Magurele (Dobrogea Centrala). Dari de Seama ale Comitetului Geologic L (2), 259-272 (in Romanian).

Mirauta O., 1965. Stratigrafia si tectonica sisturiIor verzi din regiunea Istria - Baltagesti (Dobrogea Centrala). Dari de Seama ale Comitetului Geologic LI (1), 257-276 (in Romanian).

Mirauta O.,1969. Tectonica Proterozoicului supe- 
rior din Dobrogea centrala. Anuarul Institutului Geologic XXXVII, 31-36.

Mirauta O., Mirauta E., 1961. Observatii asupra structurii geologice a regiunii Baspunar-CamenaCeamurlia de Sus (Observations on the geological structure of the Baspunar-Camena-Ceamurlia de Sus area). D. S. Inst. Geol. Rom. XLIV, 83-93 (in Romanian).

Motas C. I., 1913. Die Tuffitzone der mittleren Dobrogea und die Kieslagerstattten von Altîntepe, ein Beispiel der Epigenese. Dissertation. Berlin.

Mrazec L., 1910. Discussion sur l'existence des roches vertes en Carpathes. Dari de Seamâ ale Institutului Geologic II (in Romanian).

Mrazec L., 1912. Sur la ligne de chevauchement Peceneaga-Camena. Dari de Seamâ ale Institutului Geologic III, 162-165 (in Romanian).

Paraschiv D., Paraschiv C., 1978. Zona sisturilor verzi si relatiile ei cu celelalte unitati ale vorlandului Carpatilor Orientali din România. Studii si cercetari de geologie, geofizica, geografie, seria Geologie 1 (33), 44-57 (in Romanian).

Pavelescu L., Nitu G., 1977. Le probléme de la formation de l'arc carpatho-balkanique. Anu. Univ. Bucur. Geol. 26, 19-35.

Preda D. M., 1964. Forelandul carpatic si pozitia sa tectonica în cadrul structural-geologic al Europei (The Carpathian foreland and its position within the geological-structural setting of Europe). An. Com. Geol. XXXIII, 9-44 (in Romanian).

Radulescu D. P., Cornea I., Sandulescu I., Constantinescu P., Radulescu F., Pompilian A., 1976. Structure de la croute terrestre en Roumanie. Essay d'interpretation des études seismiques profondes. An. Inst. Geol. Rom. L, 5-36 (in Romanian).

Sandulescu M., 1980. Analyse géotectonique des chaînes alpines situées autour de la Mer Noire occidentale. Ann. Inst. Geol. Geofiz. 56, 5-54 (in Romanian).

Seghedi A., Oaie G., 1995. Palaeozoic evolution of North Dobrogea. In: Field Guidebook, Central and North Dobrogea, IGCP Project no. 369 "Comparative evolution of PeriTethyan Rift Basins", Mamaia, P. 75.

Talwani M., Worzel J. L., Landisman M., 1959. Rapid gravity computations for two-dimensional bodies with application to the Mendocino submarine fracture zone. J. Geophys Res. 64, 49-59.

Talwani M., Heirtzler J. R., 1964. Computation of magnetic anomalies caused by two-dimensional bodies of arbitrarz shape. In: G. A. Parks (Ed.) Computers in the mineral indiustries, Part 1. Stanford Univ. Publ., Geol. Sci. 9, 464-480.

Won I. J., Bevis M., 1987.Computing the gravitational and magnetic anomalies due to a polygon: Algorithms and Fortran subroutines. Geophysics 52, 232-238. 